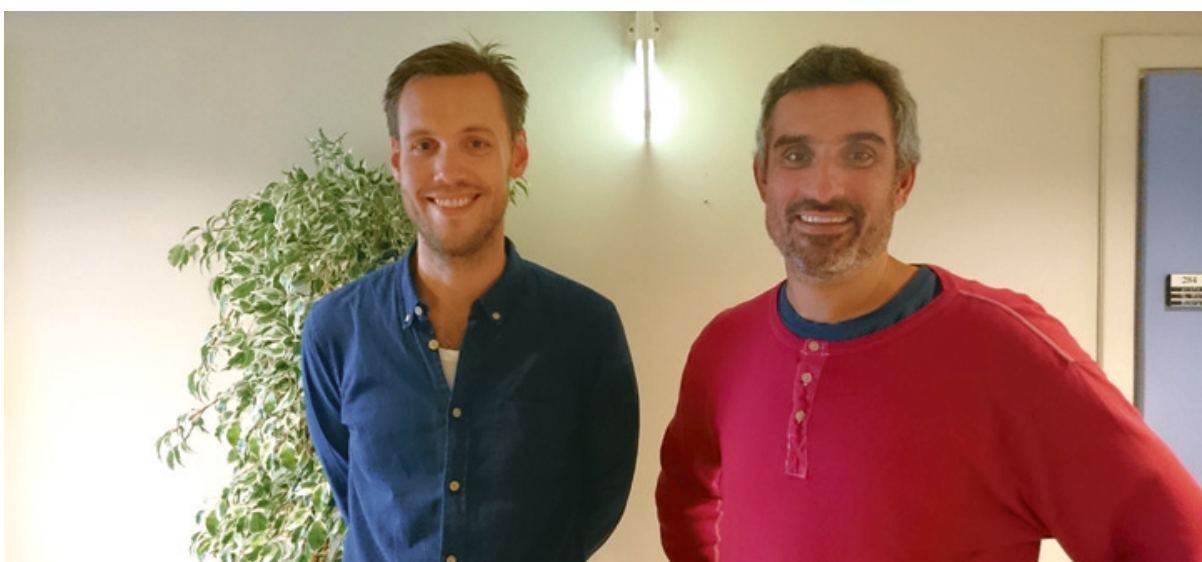

Førsteforfatter Bendik S. Fiskå (venstre) og hovedveileder Øyvind Næss. Foto: privat

MIN FøRSTE PUBLIKASJON

\section{Hjerteinfarkt hos nære slektninger påvirker risiko for koronarsykdom}

Familiehistorie med tidlig hjerteinfarkt er en uavhengig risikofaktor for koronarsykdom, og risikoen øker dersom man har både foreldre og søsken med tidlig infarkt.

At koronarsykdom i familien er en risikofaktor for selv å utvikle koronarsykdom, har lenge vært kjent. Om effekten er uavhengig av andre etablerte risikofaktorer, har derimot vært usikkert. Lavere sosioøkonomisk status har i flere studier vist å korrelere med høyere forekomst av koronarsykdom.

En norsk forskergruppe har nylig undersøkt sammenhengen mellom sosioøkonomisk status, familieanamnese og koronar hjertesykdom (1). Førsteforfatter er siste års medisinstudent i Oslo. Gruppen brukte data fra Cohort of Norway (CONOR), som er en sammenstilling av data fra ti regionale helseundersøkelser fra perioden 1994-2003. Denne kohorten omfatter over 130000 pasienter som har fått detaljerte spørsmål om tidlig hjerteinfarkt hos førstegradsslektninger, og i tillegg er det data om etablerte risikofaktorer. Dataene ble så koblet med Dødsårsaksregisteret. For over 84000 deltakere ble det også laget indikatorvariabel for sosioøkonomiske levekår basert på opplysninger fra folke- og boligtellingene, Statistisk sentralbyrå og spørreskjemaer.

For menn var tidlig hjerteinfarkt, enten det var hos foreldre eller søsken, en signifikant risikofaktor for dødelighet av koronarsykdom, også etter at det var justert for andre etablerte risikofaktorer og sosioøkonomisk status. Den høyeste risikoen hadde pasienter med søsken som hadde hatt tidlig infarkt (hasardratio 1,44; $95 \% \mathrm{KI}$ 1,19-1,75). For kvinner var risikoen økt dersom både foreldre og søsken hadde hatt tidlig infarkt (hasardratio 1,$78 ; 1,16-2,73$ ), men ikke der kun foreldre eller kun søsken hadde hatt tidlig infarkt.

- Denne studien viser at en familiehistorie med koronar hjertesykdom er en uavhengig risikofaktor som varierer i størrelse ut ifra andre faktorer, slik som kjønn og hvilken slektning som var syk, sier førsteforfatter Bendik S. Fiskå. - Studien er den første der man grundig har undersøkt betydningen av sosioøkonomisk status for denne sammenhengen. Selv om man også i vårt materiale så at lav sosioøkonomisk status gjennom livsløpet var assosiert med høyere koronar dødelighet, fant vi ingen sammenheng mellom lav sosioøkonomisk status og det å ha en familiehistorie med koronar hjertesykdom.

\section{Medisinstudent og forsker}

Studien utgår fra en epidemiologisk forskningsgruppe ved Folkehelseinstituttet og universitetene i Oslo og Bergen. Fiskås hovedveileder er Øyvind Næss, og Inger Ariansen, Sidsel Graff-Iversen, Grace M. Egeland og Grethe S. Tell har vært medforfattere. Førsteforfatter Bendik S. Fiskå har også utdanning innen statsvitenskap og historie. Gruppen er i gang med en tilsvarende studie basert på data for sykehusinnleggelser.

\section{Martine Rostadmo}

Tidsskriftet

\section{Litteratur}

1. Fiskå BS, Ariansen I, Graff-Iversen S et al. Family history of premature myocardial infarction, life course socioeconomic position and coronary heart disease mortality-A Cohort of Norway (CONOR) study. Int J Cardiol 2015; 190: 302-7.
Ordforklaringer

Cohort of Norway (CONOR): En sammenstilling av ti regionale helseunders $\emptyset$ kelser utført i perioden 1994-2003. Inneholder helsedata og blodprøver fra 173326 deltakere.

Sosioøkonomisk livsløpsstatus: Sosioøkonomisk status måles ofte ved å bruke enkeltmarkører som for eksempel utdanningsnivå. Ved å analysere sosioøkonomisk livsløpsstatus forsøker man å gi et samlet uttrykk for en persons sosioøkonomiske status over flere år, ofte fra barndommen og frem til voksenlivet, ved å bruke flere ulike indikatorer målt ved flere anledninger.

Cox-regresjonsanalyse: Statistisk metode brukt for overlevelsesanalyser, der man ser på hvordan ulike risikofaktorer virker inn på overlevelsestiden til et individ, dvs. tiden fra et individ inkluderes i en studie til dødsdato eller datoen for slutt på oppfølging. Brukes for å sammenlikne sannsynligheten for død, oftest uttrykt som såkalt hasardratio, mellom grupper med ulik eksponering for en bestemt risikofaktor.

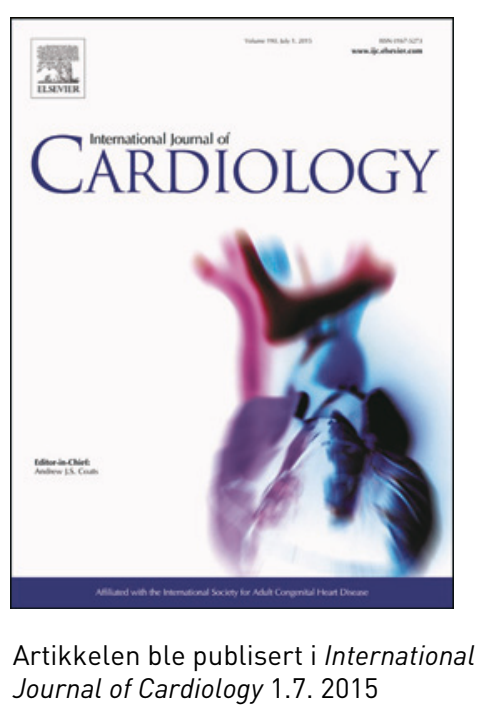

